6-3-2016

\title{
Book Review: Social Relations in Ottoman Diyarbekir, 1870-1915
}

Taner Akcam

Clark University Center for Holocaust and Genocide Studies

Follow this and additional works at: https://digitalcommons.usf.edu/gsp

\section{Recommended Citation}

Akcam, Taner (2016) "Book Review: Social Relations in Ottoman Diyarbekir, 1870-1915," Genocide

Studies and Prevention: An International Journal: Vol. 10: Iss. 1: 111-117.

DOI:

http://dx.doi.org/10.5038/1911-9933.10.1.1367

Available at: https://digitalcommons.usf.edu/gsp/vol10/iss1/11

This Book Review is brought to you for free and open access by the Open Access Journals at Digital Commons @ University of South Florida. It has been accepted for inclusion in Genocide Studies and Prevention: An International Journal by an authorized editor of Digital Commons @ University of South Florida. For more information, please contact digitalcommons@usf.edu. 
Book Review: Social Relations in Ottoman Diyarbekir, 1870-1915

\author{
Taner Akçam \\ Clark University Center for Holocaust and Genocide Studies \\ Worcester, MA
}

Social Relations in Ottoman Diyarbekir, 1870-1915

Joost Jongerden and Jelle Verheij, editors

Leiden, Brill Academic Publishing, 2012

pp. 369; Cloth: $\$ 180$

Reviewed by Taner Akçam

Clark University Center for Holocaust and Genocide Studies

An important book to read:

The most marked characteristic of Armenian genocide studies thus far is its focus almost entirely on understanding the policies of state power. Everything has concentrated on subjects like the changing government's policies, the political positions, and the evolution of political parties and ideological streams (nationalism, Islamism, Turkism, etc.) that identified the flow of events. Even when oppositional movements to central power are considered in the analyses, they have been taken up essentially as a component of the developments within the center.

There are many somewhat mundane reasons that explain why most of the research has focused on the state and its actors. The first has to do with the general characteristic of the records that we possess. The type of records you have access to will inevitably affect the way you discuss events. With the Armenian genocide-putting aside the limited number of personal memoirs touching upon local events - most of the material available on the subject narrates developments from the political center. For example, the largest component of the Ottoman archival records deals with the activities of the government. Reports that derive from regional offices are practically non-existent and the ones that do exist pertain to policies from the central office. We could say the same thing about foreign diplomatic reports, another important source of historical records.

The second reason is the unfortunate lack of a tradition with local archiving in Turkey. There is not a single city where the governor's office or the municipality maintains a formal and systematic archive. Local newspapers could have provided a good source of material but we know that they too were never systematically collected in one place. We could list other reasons why local historiography never developed, but in the end it is quite obvious that the lack of studies on local events is one of the fundamental gaps in our field.

However, during the past few years some changes in this area have been observed and local studies have picked up. ${ }^{1}$ What is notable is how Diyarbekir holds a special place in these studies. Social Relations in Ottoman Diyarbekir, 1870-1915, edited by Joost Jongerden and Jelle Verheij, is one of these studies. ${ }^{2}$ The richness of the subjects this book touches upon and some of the new approaches that it proposes will ease our ability to understand the Armenian genocide. For this reason it deserves a detailed introduction.

\title{
Preface
}

The writers have described the book's main ideas in the preface in a clear and concise way. While explaining their own personal motivation in choosing Diyarbekir, they emphasize the lack of local studies in general and point out two important errors made in connection with studies focused on the Armenian genocide. First is the teleological character around these studies. According to the editors, researchers who study a region (Diyarbekir) are "searching for clues and evidence of what

\footnotetext{
${ }^{1}$ With the emergence of oral histories, in particular, as an important field of study, studies based upon "memory" have been conducted and are being conducted. For just one example of just such a study, Adnan Çelik, Namık Kemal Dinç, 1915 Diyarbekir: Yüz Yillık Ah: Toplumsal Hafizanın Izinde, (Istanbul: Ismail Beşikçi Vakfı Publication, 2015).

${ }^{2}$ Joost Jongerden and Jelle Verheij, Social Relations in Ottoman Diyarbekir, 1870-1915 (Leiden, Boston: Brill, 2012).
} 
was later to occur, teleologically tending to ignore the elements which are not 'useful' for or even militate against their perspective" (3).

Secondly, is the nationalistic discourse which is prominent among researchers, "the tendency to view the history of the area through 'ethnic' and 'nationalistic' glasses, be it in Armenian, Kurdish, Turkish or other, and the usurpation and appropriation of other issues and narratives by and within the nationalistic discourse" (3). The editors describe their contribution to the field around the concepts of "poly-centricity" and "poly-activity." With the first, they refer to a "shift of attention from the so-called center to the so-called periphery and with the second, a move from an exclusive focus on the acts and deeds of the elite alone, to one that includes also those of multiple subaltern categories" (3).

What is referred to as "poly-centricity" is not simply an attempt to analyze the periphery; it asserts that the relationship between the central power and regional offices is not just one directional and hierarchical. Besides not being a passive recipient to the central power, regional offices act as a factor that influences and determines the former. The writers conceptualize the center-periphery relationship as one that is mutual and a dynamic structural element.

The same approach is equally applicable to local actors. Local actors are not simply engaged in implementing orders or opposing them; they function as a structural element that is present throughout the process. The editors present the practice of confiscating Armenian properties as an example of their thesis. They describe this practice as something that did not come about as a reform proposal from the top. Rather, it existed as common practice prior to the reform but took on a new shape with the implementation of reform.

\section{Chapters in the Book}

The first chapter is by Suavi Aydin and Jelle Verheij. It gives a general historical-social overview on the geography and the administrative structure of the region; it also illustrates the serious changes that occurred in Diyarbekir, which was known as the state of Kurdistan at one time, to its administrative boundaries and ethnic-religious make-up which experienced an evolution during this period. What is clear from this chapter is that up until the Tanzimat era the region was effectively 'independent' and that the central authorities carried little if any influence.

At the start of the $19^{\text {th }}$ century, those who served the government in the region were in actuality the leading families of the area. Titles would pass from father to son like legacy inheritances. The government in Istanbul started to gain control over the region when an army unit under the command of Reşit Mehmet Pasha was sent in 1834. The military operations that swept the region operated in parallel to a great degree, with the occurrence of massacres. For example, the Yezidi population of Sinjar was decimated by at least $3 / 4$ during this time.

It is an interesting fact to note that in the 1870s, the Christian population in the city center was fifty-five percent. This gives a clear indication of the extent of the ethnic cleansing that was to occur just years later. Another interesting fact that we learn is that the official regional newspaper that would begin publication in 1869 was also printed in Armenian script. Additionally, the consular offices that were established there by the French and British after 1865 were called the "Kürdistan Consulates" (45).

The Tanzimat reforms and the centralization that was a product of this movement lead to some significant social changes in the region and with it the rise of new problems. The dispersion of old traditional structures and the inability to firmly establish a new and strong administrative replacement coalesced with tribal and religious in-fighting, leading to an environment that was marked by chaos. Also during this period, foreign consular offices, missionaries, and foreign officers serving in the Ottoman army started to appear in the region; an outcome of centralization and reforms. The local population that became familiar with the new actors concurrently with the rising chaos began to view them as the cause of it.

The Tanzimat Reforms led to expanded and closer relations with foreign states and a changing social, administrative, and commercial role for Christians. This led to their attaining greater power in many areas of activity, one of the side effects of the increased activities of missionaries. Muslims connected the changing status of local Christians to the presence of these new actors. When this situation combines with a cultural foundation that already has an entrenched religious prejudice 
against the equality of Christians, it strengthened ethnic-religious segregation. Christian-Muslim tension, conflict, and massacres increased during the period of the great wars. The writers, who describe all of these factors, state that the massacres which occurred during the end of the 19th century and the start of the $20^{\text {th }}$ century can be understood through this socio-cultural back story. The Tanzimat and modernization gave way to ends that were the polar opposite of what had been conceptualized.

After this general overview, readers are presented with the specific aspects of the region's history. The second chapter by Joost Jongerden has a long title: "Elite Encounters of a Violent Kind: Milli İbrahim Paşa, Ziya Gökalp and Political Struggle in Diyarbekir at the Turn of the $20^{\text {th }}$ Century." The chapter deals with the fight amongst the regional elites that is symbolized by the names Milli Ibrahim Pasha and Ziya Gökalp. Jongerden calls these groups "Hamidian" Milli İbrahim Paşa and "Proto-nationalist" Ziya Gökalp and claims that between 1890 and 1910 both parties determined to a great degree the political development that occurred in the region. These groups are even influential with the central authorities. For example, it is possible to see the area's (Diyarbekir) influence in the process of changing the central policies from Ottomanism into Turkish nationalism; however this is not a unilateral process. One needs to speak of a dynamic process whereby each side gives shape to the other.

Jongerden presents two very important ideas. The first has to do with the Hamidian regiments. According to a prevailing view of studies on the subject, the Hamidian regiments played an important role in the Armenian massacres that occurred in Diyarbekir in 1895. Meanwhile, Jongerden believes the Hamidian regiments had not been involved in the Diyarbekir massacres and that, on the contrary, Milli Ibrahim Pasha, the commander of the Hamidian regiments in the region, had followed a policy of protecting the Christians. The chapter presents information that during the 1895 massacres many Armenians in the towns and villages of the area saved their lives by moving to Viranşehir, where Ibrahim Pasha lived.

The second important claim relates to Ziya Gökalp. Jongerden summarizes the opposing views around Ziya Gökalp's influence within the Union and Progress Party and his role in the Armenian genocide. As is well known, one of the views makes the claim that Ziya Gökalp is the theoretician of the Union and Progress party and its chief ideologue and that he played a determinative role in the decisions that were made towards the Armenians. The other view is that he did not have much influence over Unionist policies. According to this view, his ideas, which can be summarized as an amalgamation of Turkishness-Islamicism-Westernism, consisted of a pragmatic response to the Party's internal confusion rather than being the product of an original ideology. In other words, Gökalp was a follower rather than a leader.

After briefly summarizing these views Jongerden presents his own, which are that Ziya Gökalp played a large role in the development of hostilities against and persecutions of Armenians, especially in the Diyarbekir region. This is a new argument which has not been presented before and can be considered a new contribution to the field. Although Jongerden expends a great deal of effort to limit Gökalp's role in the formulation of anti-Armenian politics to Diyarbekir itself, the information he presents clearly has significance that reaches beyond regional boundaries. What we learn is that Ziya Gökalp was a small-scale 'aga' and that Armenians and Kurds had been living together in the villages that were under his control and possession. While we cannot surmise Ziya Gökalp's personal role in this, in the massacres of 1895 almost all of the Armenians in these villages were annihilated. Additionally Jongerden claims that the 'proto-nationalist' group in Diyarbekir, for which Ziya Gökalp was an important leader, held a strong anti-Armenian political stance. For example under the leadership of this group, anti-Armenianism played a role during the protests in November 1905, January 1906 and November 1907 against Sultan Abdul Hamid and especially Milli Ibrahim Pasha (and his cruelties).

The important fact is that these protests against Sultan Abdul Hamid are presented in Turkish historical accounts and even in the writings of critical historians as a progressive-revolutionary people's movement against economic exploitations and despotism! The information that this so called "progressive" movement possessed an anti-Armenian character and that Milli İbrahim Pasha's pro-Armenian policies were the basis for the accusations of the protesters against him is truly remarkable. The group around Ziya Gökalp (nationalists) was asking for the removal 
of Milli İbrahim Paşa because he had aided Armenian revolutionaries. Another important bit of information that we learn is that the regional Armenian organizations did not participate in the actions. These are indeed very refreshing contributions to our knowledge.

Joost Jongerden wants us to interpret the skirmish between the groups representing Milli Ibrahim Pasha and Gökalp within the context of a transition from empire to nation-state. According to him, Gökalp represents the embodiment of nation-statehood while Ibrahim Pasha is the representative of old imperial style policies. For Ibrahim Pasha to possess an understanding of political authority that did not take ethnic or religious identity at its central core allowed for a semblance of protectiveness for Christians, while Ziya Gökalp's nation-state outlook excludes the Christians which thereby opens the door to extermination. For this reason, during the massacres of 1895 Milli Ibrahim Pasha and his Hamidiye regiments played a 'protective' role for Armenians while the notables in the city around Pirinççizade and Gökalp group were ringleaders of the massacres.

The question remains, is it really enlightening to pit the nation-state project against the imperial concept to explain the Armenian massacres (and later genocide)? This could be the subject of a very good debate. Did the Unionists really have a project to establish a nation-state in mind when they were eradicating not only the Armenians but other Christians? Or should their efforts at ethnic-religious cleansing and homogenization of the population be understood as only within the framework of a project aimed at protecting and re-constructing the Empire? We will no doubt, be evaluating these topics for quite some time and Jongerden's arguments will have an important place in it.

The book's third chapter by Jelle Verheij is entirely focused on the Armenian massacre in Diyarbekir in 1895: "Diyarbekir and the Armenian Crisis of 1895." Verheij rightly states that there is a wealth of information about the subject in Ottoman and Western archives but that these materials have not until now been utilized in a comparative fashion. His article aims at doing this and so it is extremely valuable.

The chapter begins by drawing a general framework over the Armenian question starting from the end of the 19th century and then provides some general information around certain controversial subjects - for example population numbers, etc. The fact that the Diyarbekir's regional newspaper was published in Turkish, Arabic, and Armenian is an interesting detail. Another interesting observation that Verheij makes is that during the post Tanzimat period, modernization and increasing connections with the West brought about an improvement in the social status of Armenians living in the cities; however, the living conditions of rural Armenians deteriorated by contrast.

The chapter is not solely about the 1895 massacre of Diyarbekir as it tries to present a general evaluation of the massacres over the 1894-96 period. The role that the Sultan (the central authorities) played in the massacres is still not entirely known. Verheij is of the opinion that Abdul Hamid's role is not what the Western or Armenian sources would have us believe. In other words, he reserves some doubt that the massacres were planned and organized from the central government.

Nevertheless, this view does not render the massacres any more innocent. Quite the contrary, it reminds us that we need to approach the issue at hand from another angle, focusing on the question of mass participation during the massacres. If the massacres did not come about as a consequence of planning and following orders from above, it tells us that the massacres were the product of powerful local dynamics.

In fact, Verheij makes a multi-faceted debate around the example of Diyarbekir and explains that the massacres in the city were not limited to those that occurred between the end of October 1895 and the beginning of November but rather that there were a series of attempts at massacre that occurred throughout 1896. It was not limited to the local Muslims in Diyarbekir; Kurdish clans in the surrounding area wanted to come to the city and participate in massacres and looting. What is surprising and important to know is that it was the military garrison located in the city that actually ended up preventing many of these attempts at massacre. However, the facts on the ground are far too complex to fit into a duality between massacre hungry local powers and a central authority that is trying to oppose it. For example, the governor of Diyarbekir, obviously a representative of the government, was in charge of those amongst the local leaders who were organizing the massacres. Just this situation alone is enough to illustrate how illuminating local studies can be. 
The other important idea presented in this chapter, although it is not formulated in quite as clear a manner as the other, is the direct connection drawn between the massacres of 1894-96 and the Reform debates and packet of October 1895 that ensued after the Treaty of Berlin in 1878. Undoubtedly, this connection is not the only reason underlying the massacres. However, it was the background that provided the basis from which the massacres sprang forth. This contradictory relationship that developed between the reform efforts and the frequent use of violence provides extremely important traces to help us understand both the massacre of Adana in 1909 and the genocide of 1915.

The problem cannot simply be circumscribed by the content of the reform bill that was to be approved by the government. It is much more revealing to examine how this was being perceived in the provincial areas. In setting out how the massacres came about, Verheij proposes to include the actions of the Armenian revolutionary organizations into the analysis and the ensuing fear amongst the Muslim population of the implementation of the reforms. The point is not whether the activities of Armenian revolutionaries in question were widespread, effective, or frequent, or whether the reforms would in fact ever be implemented. In reality, the activities were extremely limited in scope and it did not appear that the reforms would ever be carried out. Verheij draws attention to the gap between reality and its perception by Muslims. Both the activities of revolutionaries and the possibility of reform took on a special form of code in the cultural worldview of Muslims and created its own special form of perception. Perception took the place of reality and formed the basis for Muslim fears. For example, in the anti-Armenian atmosphere that developed prior to the massacres, the rumor that "Armenians are going to establish an independent state" was a very effective one in terms of mobilizing masses (121).

One of the most important aspects of the chapter is the comparative analysis between Ottoman and French-British records. With these comparisons we are able to learn how the same events (for example, the massacres starting after the sound of a gunshot during the Friday prayers) are described in different reports. It is especially interesting to read how the account of the event in Ottoman records changed during its commission. For example, in the first police reports, the news that "the sound of gunshot was heard outside" would later turn into "two Muslims were injured after armed groups [Armenians] attacked the mosque" in a later record (121). Another thing that the local rulers did was to draw statements from Armenians through torture that would support their own version. To sum up, Verheij's chapter is not only the longest, but it sets the main tone with new insights to the massacres in and around Diyarbekir.

The fourth chapter by Janet Klein is about the Hamidiye regiments which Klein takes a close look at in the Diyarbekir region. She discusses the changes that occurred to the different Kurdish clans that were in the region and to their relations with each other both before and after the Hamidiye regiments. Klein's main idea is that the subject should not be approached by examining Diyarbekir alone but rather it should be evaluated by looking at the whole of all six provinces where Armenians were most numerous. Klein, who also discusses the reasons for the establishment of the Hamidiye regiments, states that approaching the subject from the perspective of the Armenian context alone leaves some things out. She recites many reasons for the creation of the Hamidiye regiments and presents border security as one of the most significant ones. She states that the Hamidiye regiments were established to combat Russian-Armenian collaboration, in other words, a potential Russian threat. If one considers that the Russians were acting in concert with Abdul Hamid, against the Armenian revolutionary organizations in the 1890s, it would seem that this thesis needs to be reconsidered. It is an open question for me whether or not Sultan Abdul Hamid did indeed fear the Russians. There are some facts that speak against such a fear. For example, the signals that Russia had given to the Sultan that they would not interfere in case there was any aggression against Armenians, as occurred in the massacres of 1894-95, had played a very crucial role. There was also military-security cooperation between both powers on the border against Armenian revolutionary activities. Ottoman-Russian relations during the 1890 s is another area that is in need of further study.

Another important observation of Klein is the social outcomes that occurred in the region as a result of the establishment of the Hamidiye regiments. According to Klein the 
Hamidiye regiments constituted the foundation for large-scale social transformations in the Kurdistan society that were not initially detected by those who had formed them. Their effects can still be observed today.

The fifth chapter by Nilay Özok Gündoğan discusses peasant dispossessions and she begins by criticizing those approaches which describe the history of the region along ethnic-religious conflict lines. She does not limit this criticism to the region alone and also includes the revolution of 1908. According to Gündoğan, the revolution of 1908 cannot be explained solely along a CUP (Union and Progress Committee) axis or with a paradigm based upon preventing the fall of an empire that was disintegrating; this revolution was also a social rebellion by workers especially those opposed to heavy taxation.

Gündoğan also draws attention to the shortcomings of the studies that have focused on the social side of the revolution of 1908. According to her, these studies are too city-centered, unduly limited to places like the Balkans, Istanbul, and Izmir and have for the most part focused on the bourgeoisie in the cities, or the relations between the retired classes and the central authorities and the CUP. Gündoğan claims that the social role of the peasants during this period, have been ignored. Also, she believes the social problems of the regions where Kurds and Armenians are most populous have especially been left out.

Gündoğan discusses how the changes to the management of land in the region of Diyarbekir, affected the peasantry and disagrees with looking at the developments in the region entirely through the lens of ethnic-religious conflict. She states that the net of social-economic relations, something that operates beyond ethnic-religious differences, were important in determining the direction of developments. It is possible to view the problems of Kurdish and Armenian peasants through a common perspective within this framework.

Another idea put forth by Gündoğan is that the studies around this region have been centered on elites only. The leading Kurdish clans of the region, and/or its most powerful families or the various cultural-political organizations that were formed by the latter, or the various socialrevolutionary activities of Armenians have been the primary focus of these studies. Starting with the written grievances that were dispatched by peasants to the central authorities, she attempts to develop a new historiography that isn't centered on elites, by placing a new social actor into the mix. The ideas that she is presenting are important but it is debatable whether a study that is circumscribed by the written grievances of peasants is enough to defend the general theoretical framework that has been drawn.

The chapters by Emrullah Akagündüz and David Gaunt, meanwhile, are focused on the Syriac Christians in the province of Diyarbekir and their relations with other groups. The information imparted by Akagündüz's heretofore little known "Mardin Collection" which uses some of the filings that were preserved in the Kurklar Church is very edifying. These filings contain the communications of the Syriac community with the central authorities, along with various court decisions. If you consider that these types of filings would most likely be found in the central government's archives, the fact that they are in the possession of a church places a special significance on those sources. Meanwhile in his chapter, Gaunt takes on the meaning of different terms like Syriac and Assyrian, discusses them, and describes how Assyrian relations, especially with Kurds, deteriorated over time and lead to massacres.

The last chapter in the book by Uğur Ümit Güngör covers what happened in Diyarbekir during the period between 1919 and 1925. Güngör's main idea could be summarized as "continuity." According to this idea, the polities of violence directed by the Union and Progress towards Armenians, and by Kemalists against Kurds, are directly related to the respective goals of creating a nation-state by both political circles. According to Güngör, both the Unionists and the Kemalists followed policies aimed at homogenization upon a Sunni-Turkish foundation and a desire to form a nation-state. There are, in truth, many valid points to be made in asserting a thesis of continuity from Unionists through Kemalism. However, is this a linear continuity as Güngör claims? The central questions that we need to answer are how accurate is the view that the political program of the Unionists aimed at the formation of a nation-state? Can we interpret and explain the Unionist and the Kemalist movements from the same "nation-state formation" paradigm? In my opinion, rather than a clear nation-state program, the Unionists were more interested in an Imperial plan 
of expansion into new regions. For this reason Güngör's linear continuity thesis is somewhat problematic and requires more detailed analysis.

The other problematic idea in the chapter is the one asserted on the Kurdish migrations of 1916. Güngör believes these forced migrations were the product of pre-planned policies from the central authorities. As far as I know, these migrations were not planned in advance and had in fact come about as a collateral effect of war. The Unionists were searching for a solution to an unexpected situation that was in line with their Imperial mindset. For example, in the document that pertains to the migration of Ahlat Kurds which Güngör uses as evidence of policies by the central government, a local solution to a situation brought about by military authorities is discussed. ${ }^{3}$ The central government is simply requesting information about this relocation of which it has received news. This subject deserves a deeper more detailed discussion.

As a last point, I would like to direct special attention to one point that Güngor highlights. He considers the negotiations for Armenian Reform in 1913-14 and the signing of an agreement at their conclusion to be one of the main reasons that triggered the local massacres during the Genocide of 1915. The parallels that can be observed between the 1915 and the 1895 massacres are truly remarkable. The similarities between the letter written in 1895 to the central government by the notables of Diyarbekir because of the Reform issue, which is presented in full, unedited in Verheij's chapter (pp. 124-126) and the writings from Diyarbekir's local authorities to the government that Güngör publishes (pp. 273-5) are stunning. All the expressions made by the notables of Diyarbekir (both in 1895 and 1914) that they are ready to spill blood to prevent the Reform show us that there is a strong relationship between the massacres of 1895 and 1915 and the respective Armenian reforms that had preceded each of them. This connection is crucial to understanding the policies of violence that were directed towards Armenians.

In summary, we have a very important study here. One that I hope will provide an impetus for further similar studies.

${ }^{3}$ BOA/DH.ŞFR.,no:57/275, coded telegram from the Ministry of the Interior to the province of Diyarbekir, dated 3 November 1915. 